\title{
THE HELLENISTIC SCENE BUILDING OF THE THEATRE AT MESSENE
}

\author{
Consideration of its original form and Roman reused blocks \\ 古代都市メッセネのヘレニズム劇場の舞台建物に関する研究 \\ その推定復元とローマ時代の転用材に関する考察
}

Ryuichi YOSHITAKE ${ }^{* 1}$ and Mitsuki YAMAZATO*2

吉武隆一, 山里光季

\begin{abstract}
This paper reports on the analysis of the original form of the Hellenistic scene building of the Messene Theatre, which is believed to have consisted of two parts: a proskenion consisting of a 26.5-m-long Ionic colonnade with wooden pinakes, and a skene with three thyromata to provide costume-changing space for actors. Through the analysis, it was also determined that the Roman scene building was constructed by systematically reusing the architectural blocks of the Hellenistic scene building. The normal Ionic column drums of the pulpitum appear to have been transported from another building, most certainly the Arsinoe Fountain.
\end{abstract}

Keywords : Hellenistic architecture, Theatre, Scene building, Restoration, Reused block ヘレニズム建築, 劇場, 舞台建物 , 復元 , 転用材

\section{Introduction}

Much has been written about Greek Hellenistic theatres, and previous investigations of the most well-preserved Hellenistic theatres, such as those found in Priene $^{1)}$ and Epidauros ${ }^{2}$, have provided us with basic knowledge on Hellenistic theatre construction, especially on their stone scene buildings, which normally consisted of a high raised stage (proskenion/logeion) and a two-storied scene buildings (skene) $)^{3}$. In contrast, there is limited information on other Greek theatre forms in the east because of later period rebuilding, primarily dismantling and reforming during the time of the Roman imperial period. At that time, most Hellenistic scene building had been transformed from their original Greek traditional style to reflect the Roman contemporary style. However, thanks to the recent excavations, new information on Hellenistic scene buildings regarding the theatres at Aigeira ${ }^{4}$, Eretria ${ }^{5}$, Delos ${ }^{6}$, and Apollonia ${ }^{7)}$ has become available to scholars. As a result, attention is now being focused on the architectural context of the Hellenistic scene buildings ${ }^{8)}$, with scholars paying particular attention to the dismantling and the rebuilding of the scene building9).

In the case of the Hellenistic scene building at the Messene Theatre, it is particularly noteworthy that the majority of the foundation of the Roman scene building was constructed by reusing blocks from the previous building ${ }^{10}$. Based on our recent survey of 2016, these reused blocks appear to have been extracted, modified, and incorporated into the new structure in a systematic manner. In this context, the present paper aims to report our recent observations of the original Hellenistic scene building, and to estimate its original form by considering the reused material with related Hellenistic scene buildings ${ }^{11}$. It should be noted that the present article has been partly appeared in the previous report ${ }^{* 11}$.

\section{Remains of the Hellenistic scene building}

Most of the preserved scene building remains trace back to the Roman period rather than the earlier Hellenistic period, which is normally placed in the second half of the second century B.C. ${ }^{12}$. The Roman scene building plan consisted primarily of three parts, stage front (proscaenium or frons pulpiti), stage (pulpitum), and scaenae frons wall (Fig. 1). Although no portion of the wooden stage floor has survived to the current position, a northeast view of the openair pulpitum can be seen in Fig. 2. This photograph also shows the long narrow foundation of the Hellenistic proskenion. This foundation, which is located between the stage pillars and the foundation of the scaenae frons, was approx. $26.55 \mathrm{~m}$ long and 0.90 to $1.10 \mathrm{~m}$ wide, and was made of two parallel lines of

\footnotetext{
* 1 Assoc. Prof., Priority Organization for Innovation and Excellence, Kumamoto University, Dr.Eng.

*2 Grad. Student, School of Science and Technology, Kumamoto University, B.Eng.
}

\author{
熊本大学大学院先導機構 准教授·博士 (工学)




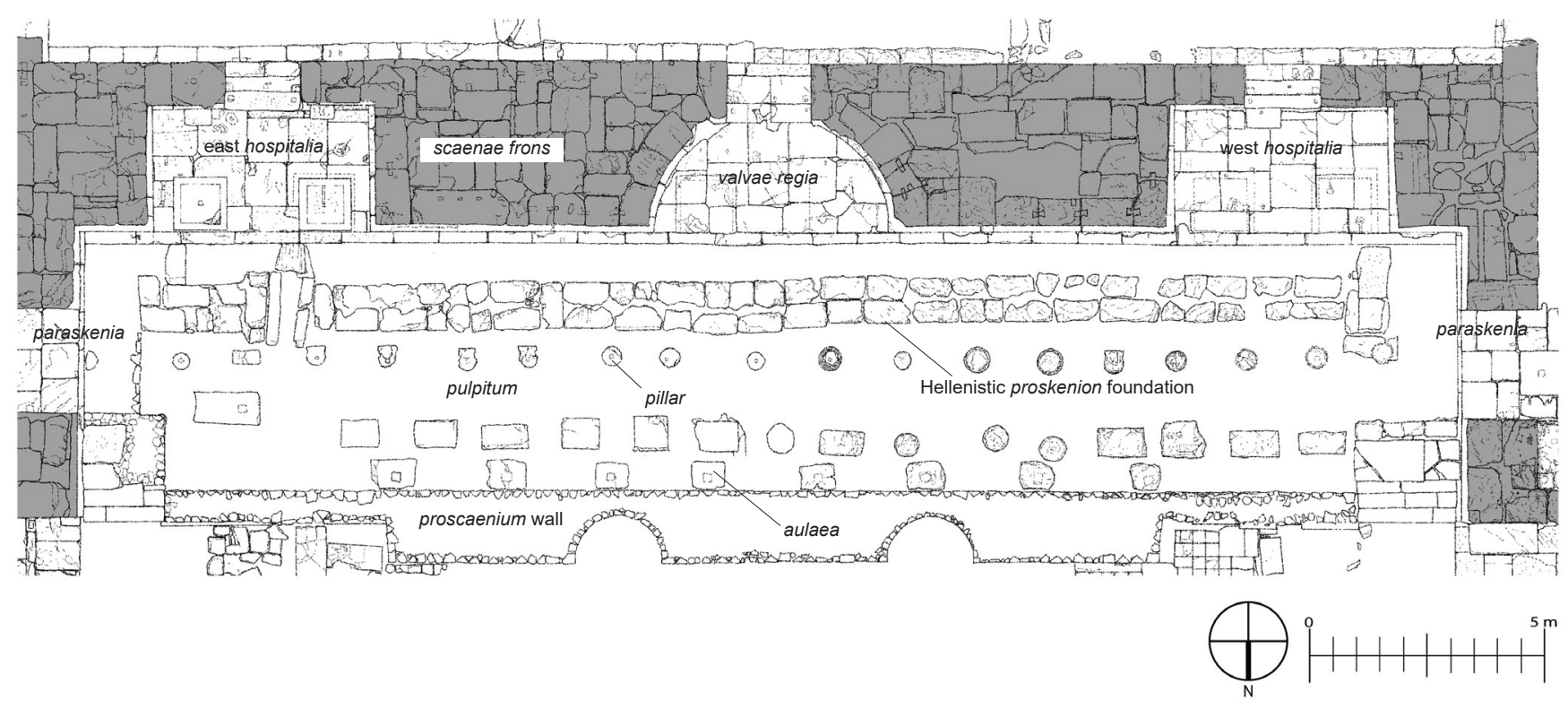

Fig. 1 Messene. Plan of the Roman scene building (drawned by Architectural Team of Kumamoto University, 2008-12), scale 1:200

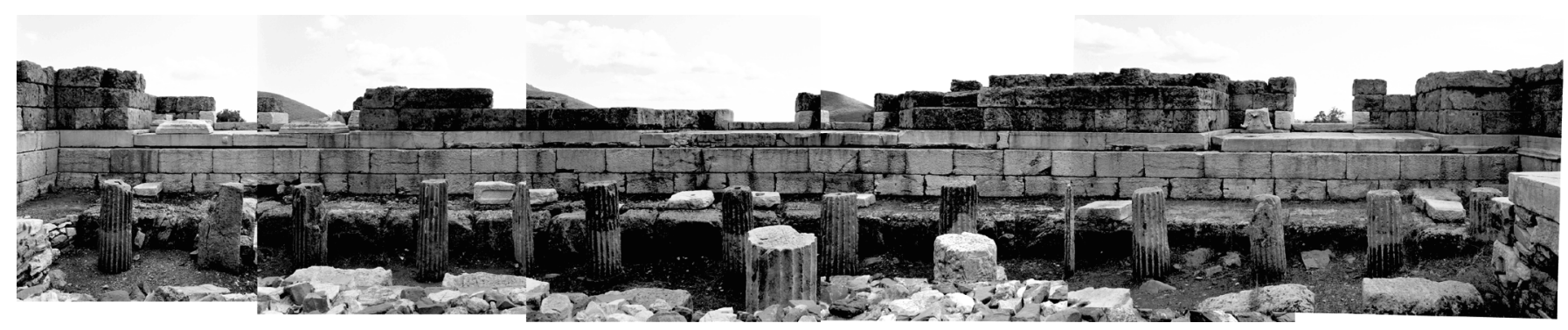

Fig. 2 Photo-montage of the north elevation of the Roman scene building (photo by Ito, J.; montage by Yamazato, M.)

poros stone, which was a common building material not only in the high Hellenistic time of Messene's history, as evidenced by the Stoas of the Asklepieion ${ }^{13)}$ and the Arsinoe Fountain ${ }^{14}$, but also in Hellenistic architecture elsewhere on the Greek east.

The upper face of the poros stone foundation is approx. $1.15 \mathrm{~m}$ lower than the floor of the three niches of the two hospitalia and central valvae regia, and is separated by $0.65 \mathrm{~m}$ from the Roman scaenae frons foundation at the west end, and about $0.85 \mathrm{~m}$ from east end. Thus, rather than running parallel to the Roman scene building, the axial line of the poros stone foundation is offset counterclockwise by about 1 degree, probably because of a construction error $^{15)}$. Both ends of the poros foundation are $1.20 \mathrm{~m}$ separate from the paraskenia. The L-shaped corner of the west end of the poros foundation indicates the end of the proskenion. Although no similar traces can be seen on the east end, when viewing from the interior, a poros stone can be seen under the proscaenium wall, so it is likely that there was a L-shaped corner at both ends of the Hellenistic proskenion, probably accompanied by the Hellenistic paraskenia. The proskenion foundation is the only surviving portion of the Hellenistic scene building that remains in situ.

\section{Hellenistic scene building and Roman reused block}

The author's investigation and new observations of the Roman scene building reveal that Hellenistic architectural materials had been reused in parts of the Roman scene building. It is conjectured that when the Roman scene building was constructed in the second half of the second century B.C., most parts of the architectural members of the former Hellenistic scene building were carefully dismantled and incorporated into the design of the Roman scene building. Those reused architectural members include not only the proskenion foundation and Ionic attached half-column drums, but also blocks of the skene wall, the architrave-cornice, and the backer of the skene building, etc.

\section{3-1. Proskenion foundation}

It is suspected that all of the floor slabs of the two hospitalia and the central valvae regia niches were originally reuse from the foundation of the Hellenisric proskenion. Fig. 3 shows another northeast view of the Messene Roman scene building, while Fig. 4 shows the plan of the east hospitalia. The floor slabs of these niches is approx. 0.233 to $0.30 \mathrm{~m}$ high ( 8 measurements) and believed to be the stylobate of the proskenion. The proskenion foundation was constructed very simply and the height of the stylobate block was varied ${ }^{16}$. It is not possible to identify the original thicknesses of these slabs because they were modified to fit into each of the niche floors, but the thinnest slab was measured as $53 \mathrm{~cm}$ on the east hospitalia, which is slightly bigger than the depth of the candidate arrached Ionic half-column drum of approx. $50 \mathrm{~cm}$, as discussed below. In any event, the thicknesses of the stylobate blocks varied as well, probably because 


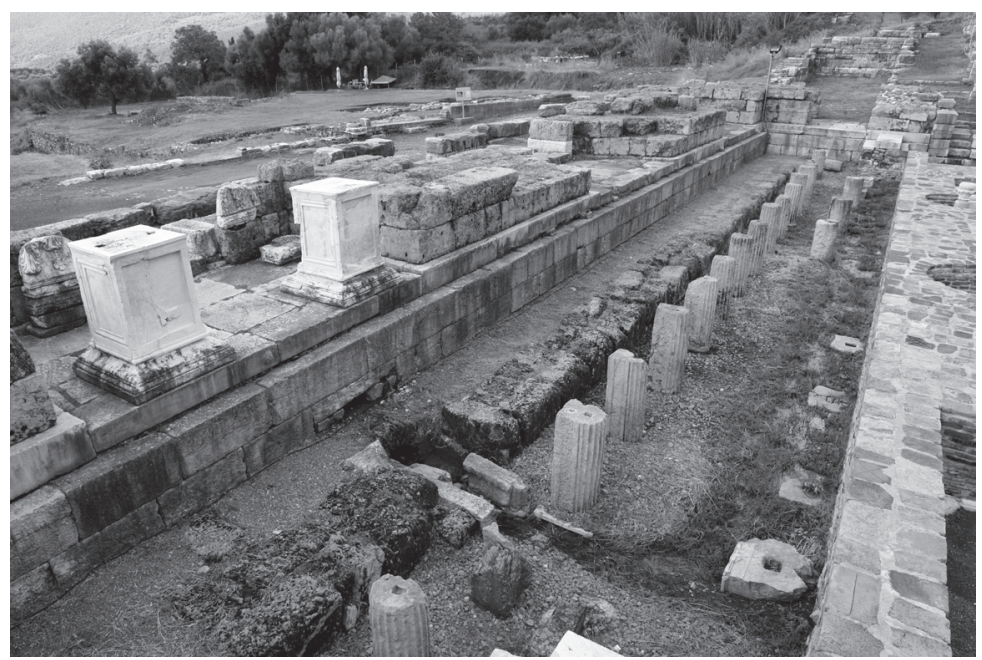

Fig. 3 Messene. View of the Roman scene building from the northeast, 2016 (photo by Yoshitake, R.)

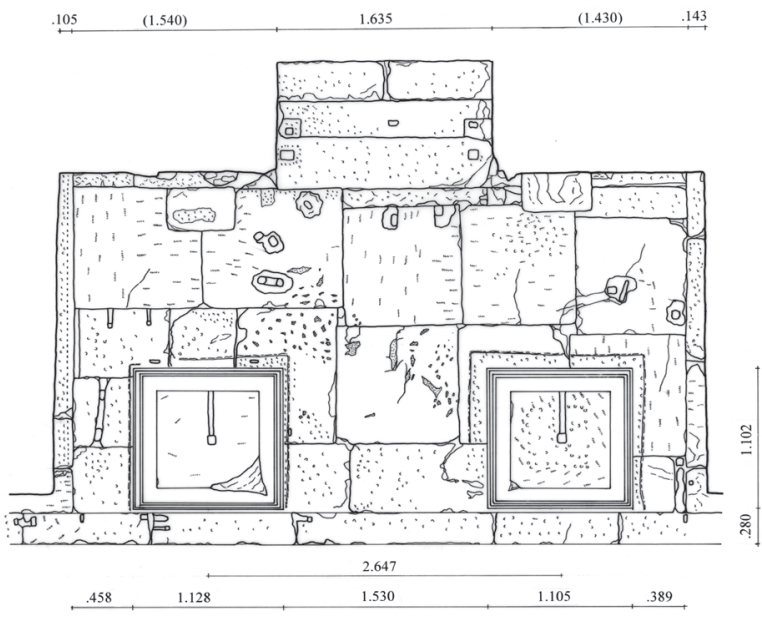

Fig. 4 Messene. Plan of the east hospitalia (drawn by Adachi, Y.), scale 1:75

there was no need to keep the back side of the stylobate straight ${ }^{17}$.

\section{3-2. Ionic columns of the proskenion}

The wooden stage floor was supported by 18 stone pillars that were originally produced in the Hellenistic period (see Figs. 1-3, Table 1). There are two pillar types: Ionic attached half-columns and Ionic normal columns. Both column types were cut at heights of appropriately 1.2 to $1.3 \mathrm{~m}$ to support the Roman wooden stage. The Ionic attached half-column drums consisted of six blocks 0.37 to $0.43 \mathrm{~m}$ in diameter and 0.48 to $0.49 \mathrm{~m}$ in depth. Fig. 5 shows a photo of an Ionic attached half-column drum (T64), while Fig. 6 shows a drawing of the same column. These blocks were equipped with slots (approx. 12 to $16 \mathrm{~cm}$ wide and $3 \mathrm{~cm}$ deep) on both sides, thereby suggesting that they were originally fabricated to hold prepared wooden painted panels (pinakes) for use in the proskenion. The front sides of the Ionic attached half-column have 10 flutes.

A normal Ionic column consists of 12 blocks and has a lower diameter of 0.45 to $0.48 \mathrm{~m}$ (4 measurements). Fig. 7 shows a normal Ionic column drum (T57), while Fig. 8 shows a drawing of the same column drum. Four of those blocks are the bearing base, but because of the modern reconstruction work, it was possible to identify the attic-type moulding of Block No. T57 only ${ }^{18}$. Normal Ionic columns also have 20 flutes, as double number of 10.

Both column types were made of local poros stone. The columns were finished with stucco, as seen in the case of the other two Messene public buildings mentioned previously. In particular, it was noted that flute sections of both columns type are quite similar to each other, as well as to the Corinthian columns of the Stoa of the Asklepieion ${ }^{19)}$ and Ionic columns of the Arsinoe Fountain ${ }^{20}$. Taken together, the characteristics of both column types are indications

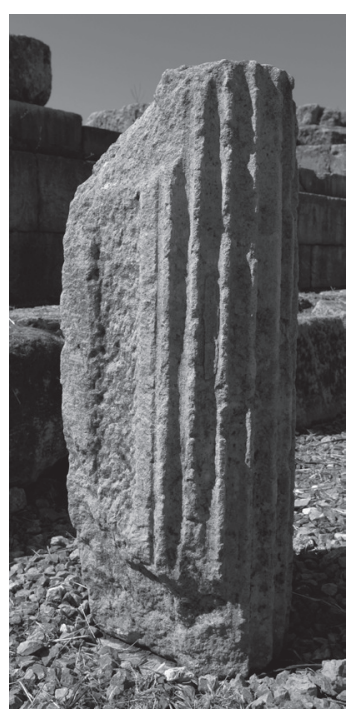

Fig. 5 lonic attached halfcolumn drum (T64), 2016 (photo by Yoshitake, R.)
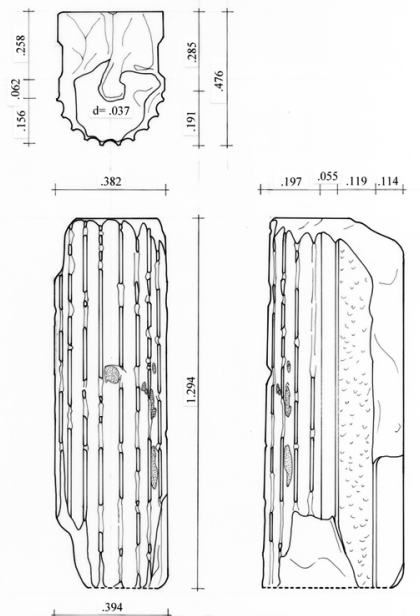

Fig. 6 Drawing of Ionic attached half-column drum (T64) (drawn by Yamazato, M.), scale 1:30

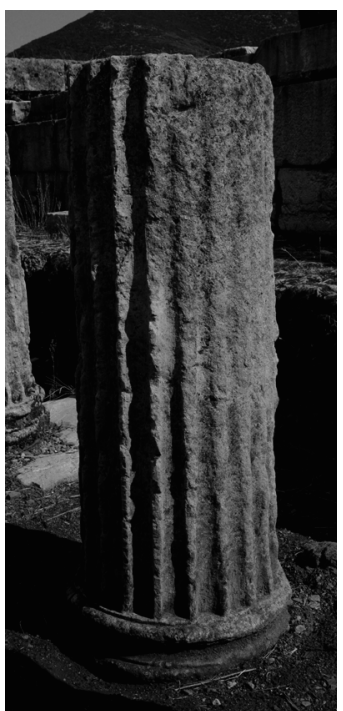

Fig. 7 Normal lonic column drum (T57), 2010 (photo by Ito, J.)
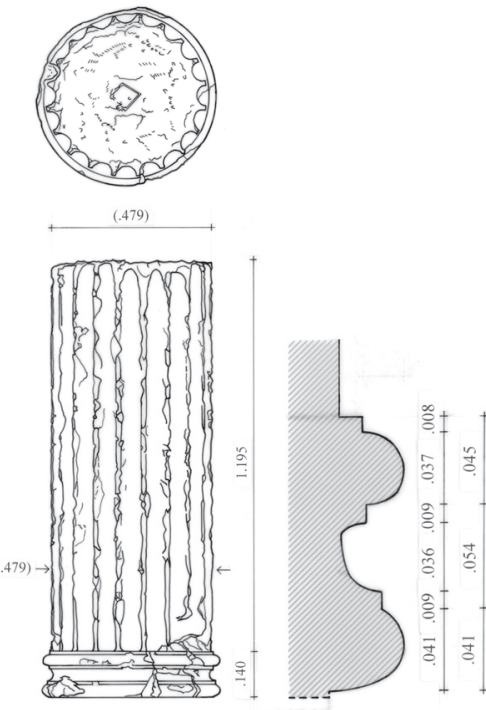

Fig. 8 Drawing of the normal lonic column drum (T57) (drawn by Mitsuyama, A.), scale 1:30 (column), 1:5 (moulding profile) 
that they were originally from former public buildings of the Hellenistic period that had been produced. 3-3. Ionic attached half-capital of the proskenion

In the survey discussed below, which was conducted in 2012, some pieces of an Ionic column drum were discovered near the northeast corner of the Agora, as shown in Fig. 9. These architectural blocks include some Ionic attached half-capitals with necking. The upper diameter of the column was approx. $34 \mathrm{~cm}$, and the depth of the block was approx. $50 \mathrm{~cm}$. The attached half-columns are dressed by 10 flutes on each front side, and both sides of the necking have slots that are approx. $15 \mathrm{~cm}$ wide. The given dimensions and stylistic characteristics clearly indicate that these architectural blocks were originally part of the Hellenistic scene building. While their archaeological context is not yet clear, it seems certain that these Ionic attached half-capital blocks were reused in public buildings of the agora, during the time of Roman imperial period ${ }^{21)}$.

\section{3-4. Wall blocks of the skene}

The platform and podium of the Roman scene building was almost completely founded in reused cutstone from the Hellenistic period. Fig. 10 shows detail of the Roman scene building platform. The scaenae frons platform was made of white limestone from the bottom up to the floor level, but the wall of the scaenae frons consisted of brown poros stone, as can be seen in Fig. ${ }^{22}$. Here, we can see how the limestone and poros stone blocks were converted into the north elevation of the scaenae frons foundation, which faces the pulpitum (Fig. 10). On the lower part of the foundation, there are two courses of ashlar limestone arranged in isodomic masonry technique. The lower course is approx. $0.41-0.43 \mathrm{~m}$ in height, while the upper course is approx. $0.48 \mathrm{~m}$ in height. The third row forms a step to support a wooden floor.

What is remarkable about this feature is that there are dowel-tailed clamp traces on the vertical face (observing surface) of the lower course (rather than on the top face), but not that of the upper course. Details of the Roman scene building foundation can be seen in Fig. 10. These clamp traces
Table 1 Messene. List of lonic attached half-column and normal Ionic column drums of the pulpitum

Ionic attached half-column

\begin{tabular}{|c|c|c|c|}
\hline $\begin{array}{c}\text { Number } \\
\text { (from E to W) }\end{array}$ & $\begin{array}{c}\text { Block } \\
\text { height } \\
(\mathrm{m})\end{array}$ & $\begin{array}{c}\text { Upper } \\
\text { diameter } \\
(\mathrm{m})\end{array}$ & $\begin{array}{c}\text { Lower } \\
\text { diameter } \\
(\mathrm{m})\end{array}$ \\
\hline$\Theta 1$ & & 0.403 & 0.405 \\
\hdashline T59 & 1.207 & 0.399 & 0.429 \\
\hdashline$\Theta 3$ & & 20.393 \\
\hdashline T58 & 1.310 & 0.368 & 0.423 \\
\hline T64 & - & 0.383 & 0.400 \\
\hdashline T56 & 1.289 & 0.399 & 0.414 \\
\hline Average & 1.269 & 0.391 & 0.414 \\
\hline
\end{tabular}

normal Ionic column drum

\begin{tabular}{|c|c|c|c|}
\hline $\begin{array}{c}\begin{array}{c}\text { Number } \\
\text { (from E to W) }\end{array} \\
\end{array}$ & $\begin{array}{l}\text { Block } \\
\text { height } \\
\text { (m) }\end{array}$ & $\begin{array}{c}\text { Upper } \\
\text { diameter } \\
(\mathrm{m})\end{array}$ & $\begin{array}{l}\text { Lower } \\
\text { diameter } \\
(\mathrm{m})\end{array}$ \\
\hline$\Theta 2$ & & 0.422 & 0.435 \\
\hline$\Theta 5$ & & 0.426 & 0.464 \\
\hline$\Theta 6$ & & 0.432 & 0.445 \\
\hline$\Theta 7$ & & 0.414 & 0.435 \\
\hline$\Theta 8$ & & 0.460 & 0.474 \\
\hline$\Theta 9$ & & 0.436 & 0.463 \\
\hline$\Theta 10$ & & 0.470 & 0.475 \\
\hline T57 & 1.335 & 0.479 & 0.479 \\
\hline T55 & 1.191 & 0.429 & 0.480 \\
\hline$\Theta 11$ & & \multicolumn{2}{|c|}{0.441} \\
\hline$\Theta 12$ & & 0.463 & 0.476 \\
\hline$\Theta 13$ & & \multicolumn{2}{|c|}{0.427} \\
\hline Average & 1.263 & 0.442 & 0.463 \\
\hline
\end{tabular}

are, of course, not intended to connect with each other, but they do prove that the blocks were reused. After all, the height difference of these two foundation courses indicates that the upper course blocks were reused in the original direction. In contrast, the lower blocks were rotated so that what was originally the top or bottom faced outside. The standardized dimensions of the limestone used in both courses also support this interpretation. Thus, it can be said that these two sets of blocks were set facing each other to form the wall of the skene, and were bound together with clamps.

From an examination of the mason marks observed on the limestone foundation surfaces, it can be conjectured that this conversion was undertaken by local stonemasons in a systematic way. Fig. 11 shows mason's marks on the Roman scene building ${ }^{23}$. The first course has numeric alphabet marks in sequence from east to west - A, A-B, B- $Г, \ldots, \Psi-\omega-$ which were obviously used as references. The second course was originally marked with B, meaning 'second' course, by adding marks before or after: AA-B, BB- $\Gamma, \Gamma \mathrm{B}-\Delta, \Delta \mathrm{B}-\Delta$, etc. This supports our interpretation of the systematic incorporation of architectural blocks from the rear wall of the Hellenistic scene building into the Roman scene building ${ }^{24}$.

\section{3-5. Architrave-cornice and backer of the skene}

The third course of the Roman scene building platform, which can also be referred to as the stylobate and toichobate of the scaenae frons wall, is set slightly

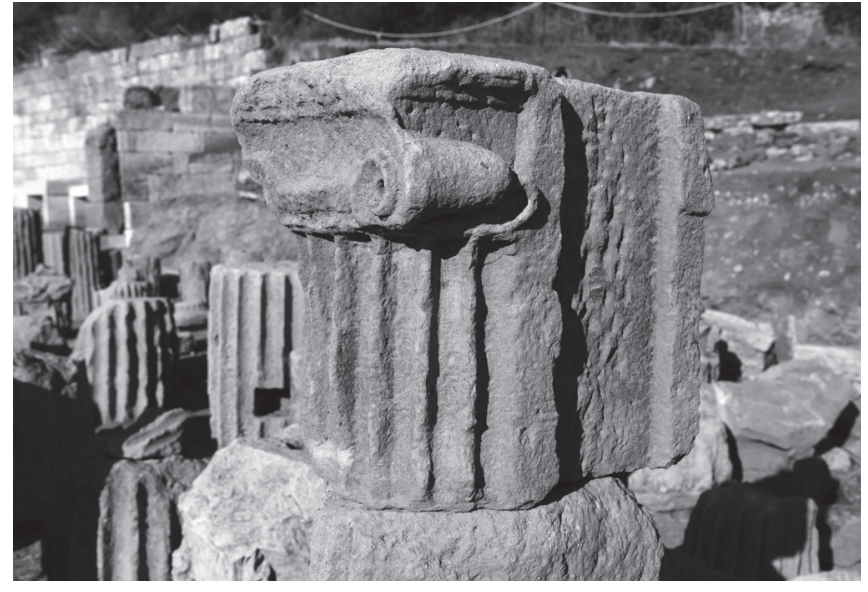

Fig. 9 Messene. Ionic attached half-capital from the northeast part of the agora, 2012 (photo by Yoshitake, R.)

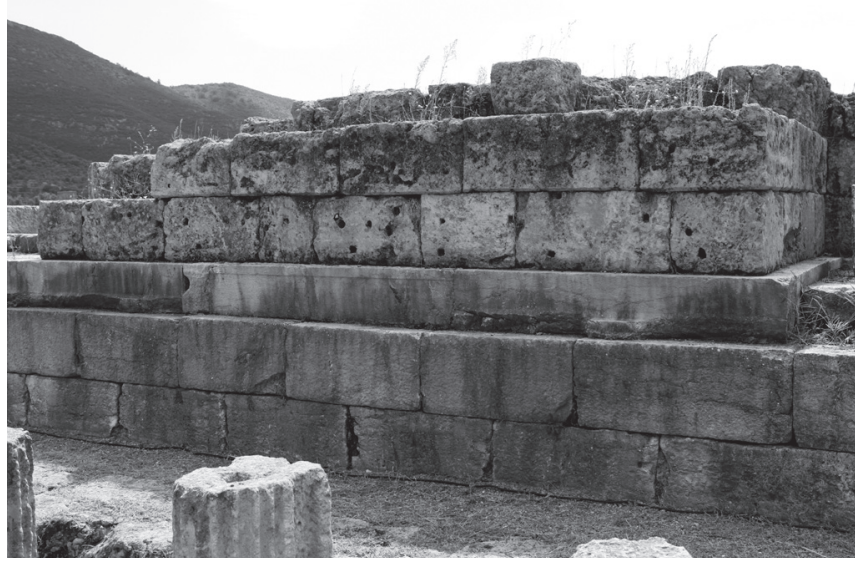

Fig. 10 Messene. Foundation of the Roman scaenae frons, 2016 (photo by Yoshitake, R.) 
H

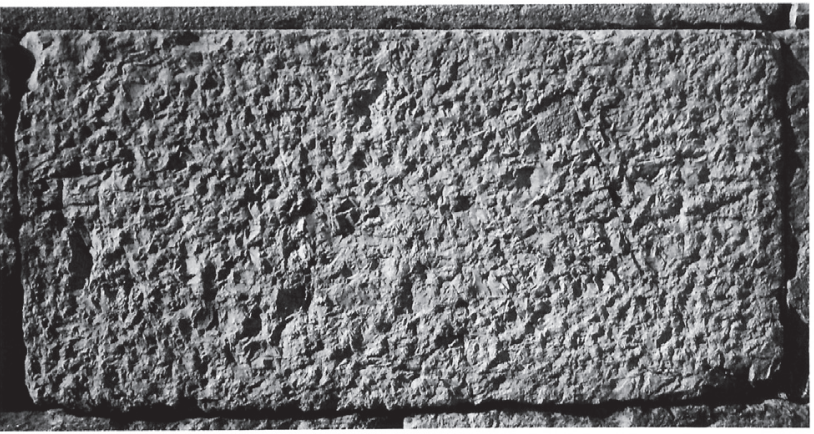

Fig. 11 Messene. Mason's mark on the Roman scene building (after Themelis 2015, fig. 15)

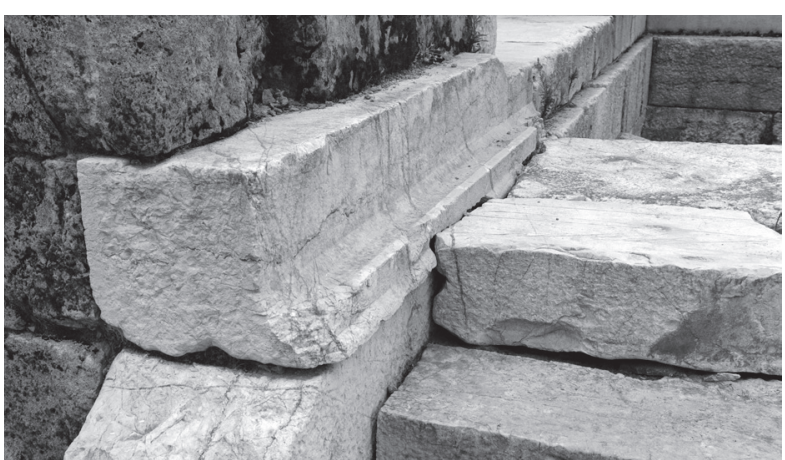

Fig. 12 Messene. Detail photo of east wing of the Roman scene building (photo by Yoshitake, R.)

lower than the two abovementioned foundation courses. The blocks of this course are carefully placed approx. $25 \mathrm{~cm}$ back from the second course in order to provide a space to hang beams for the wooden stage floor (Fig. 3). These limestone blocks are approx. $0.36 \mathrm{~m}$ in height, which is somewhat lower than the former lower two courses, and were prepared not only for use along the Roman stage but also in the margins of the three niches, probably so that they could be visible from the audience. The back sides were made of reused poros stone, just like the upper courses. Some of the front blocks bear a narrow course of moulding on the bottom of the face, while other blocks bear a narrow taenia on the top instead of moulding (see Figs. 4 and 12 for details).

The original measurements are as follows. The average architrave-cornice block is $0.36 \mathrm{~m}$ in height (7 measurements) and $0.35 \mathrm{~m}$ in bottom width (6 measurements), whereas the backer is approx. 0.35 to $0.36 \mathrm{~m}$ in height ( 2 measurements) and approx. $0.34 \mathrm{~m}$ in bottom width ( 1 measurement). Based on our knowledge on Hellenistic period stone scene building, we can conjecture that the skene was built in rough finished stone masonry, and no ornamentation (such as the order of the proskenion) was ever applied ${ }^{25}$. If we keep in mind the careful treatment of elevation in reference to Hellenistic public buildings, it might be not curious if the grave monuments of the Messene gymnasium-complex are taken up as candidates for comparison. Indeed, the profile of the crowning moulding of the architrave-cornice block is quite similar to those seen on two of the grave monuments ${ }^{26}$.

The architrave-cornice block consisted of two parts: the architrave and the crowning moulding, either with or without dentil moulding. Owing to its service as the doorway lintel, one block (K3.46) received special treatment: Its central part bears three faciae instead of two, so it can be used to estimate the total height of the 'original designed' blocks. Its height, $0.365 \mathrm{~m}^{27)}$, is as same as the architrave-cornice blocks ( 0.35 to $0.36 \mathrm{~m}$, as mentioned above). It is said these grave monuments were built between the end of the third and the middle of the second century B.C. ${ }^{28}$, which is close to the period when the Hellenistic scene building was erected ${ }^{29}$. Taking into consideration this parallel example, it can be said that these architrave-cornice blocks originally belonged to the Hellenistic scene building, most likely the skene wall.

The lengths of the architrave-cornice blocks vary from 1.647 to $2.23 \mathrm{~m}$ (7 measurements) and the backer blocks are from 1.907 to $1.950 \mathrm{~m}(2$ measurements), neither of which include their original lengths. Here again, the reason for the irregularities might be because blocks from the Hellenistic scene building were reused. The cornice was reused upside down from the original form to prevent it from obstructing the space that it was prepared for, but this was probably not necessary for the backer blocks, which could be used as facing with the original outer face and taenia on the top.

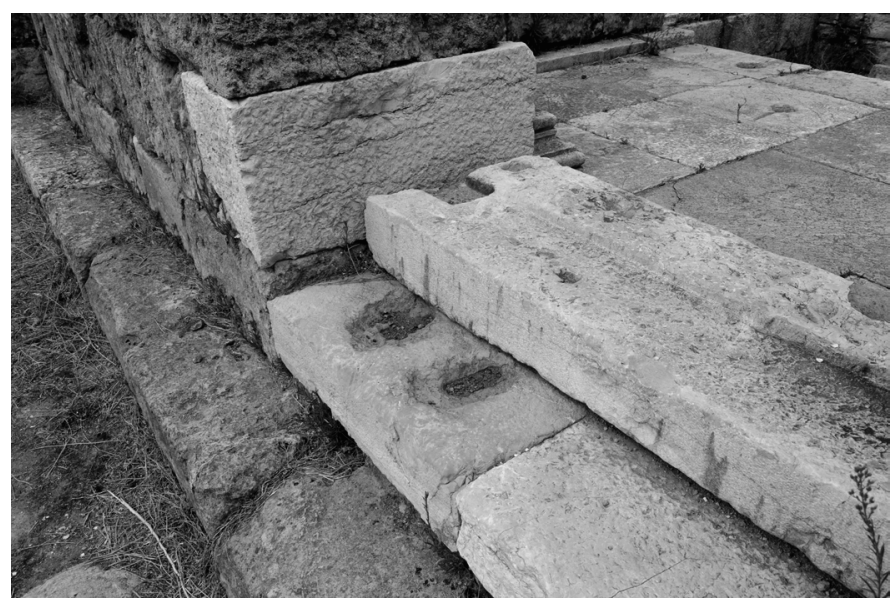

Fig. 13 Messene. Detail of the stairway of the west hospitalia niche, 2016 (photo by Yoshitake, R.)

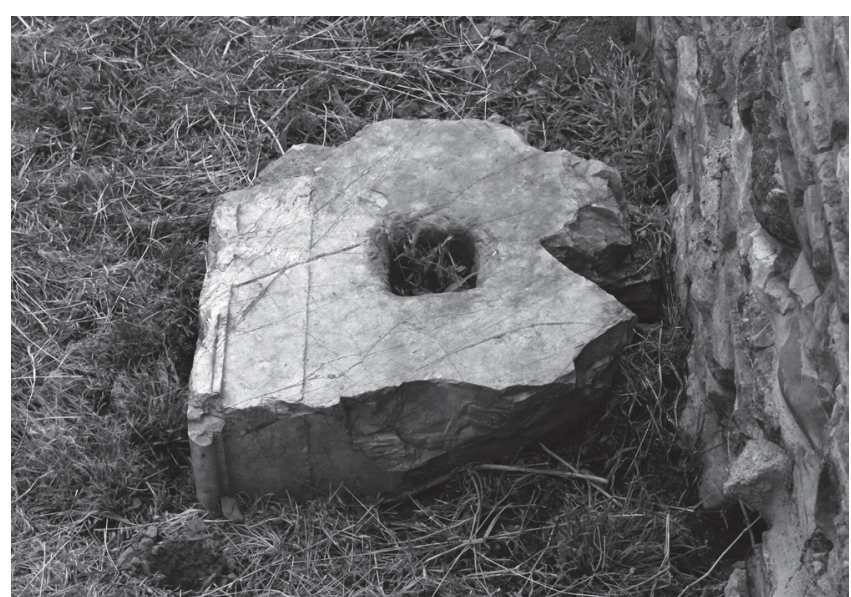

Fig. 14 Messene. Support of the wooden pillar of the aulaeum in the pulpitum (photo by Yoshitake, R.) 


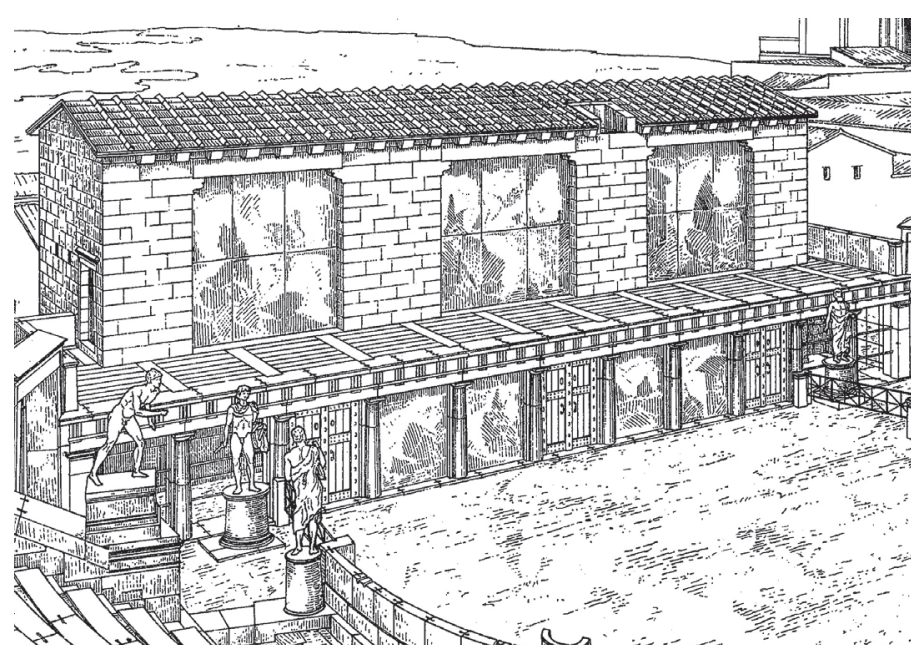

Fig. 15 Priene. The Hellenistic scene building, restored (after von Gerkan 1921, pl. 35)

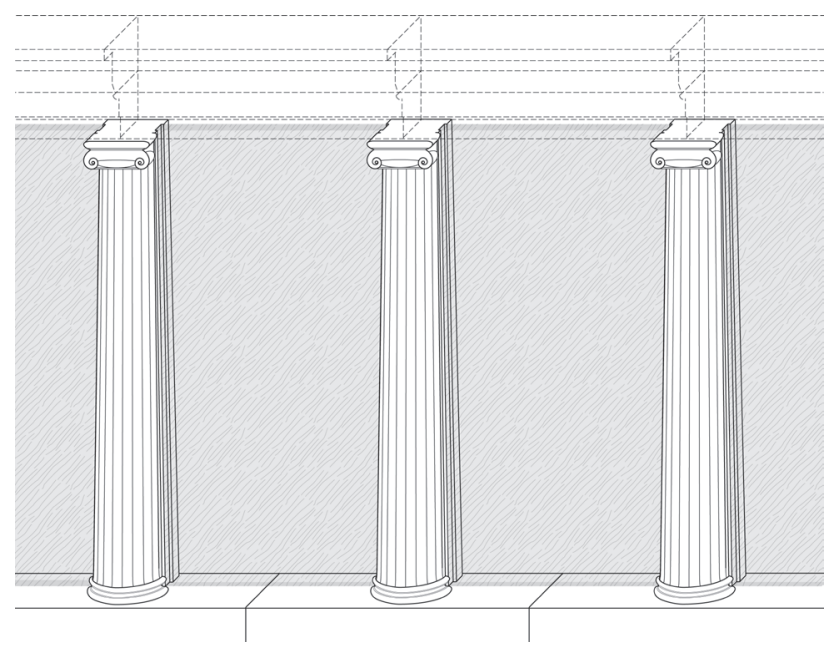

Fig. 16 Messene. Hypothetical restoration of the Hellenistic proskenion (drawn by Yamazato, M.), scale 1:60

\section{3-6. Skene wall blocks?}

The fourth to sixth courses of the scaenae frons foundation (Fig. 10) are roughly the same height (43 to $47 \mathrm{~cm}$ ). They are made of poros stone, instead of limestone, and bear double-tailed clamp traces on the top of both the ends of the longer side. These clamps are inconsistent with the neighbouring blocks but are only found on the front row of the scaenae frons wall. Here again, mason's marks can be observed. The symbols become more complex, with addition of either a " $\Delta$, , ('fourth' course) or a combination where the "letter $C$ " is inscribed facing either right or left of the identifying letter ${ }^{30)}$. It is still unclear which part of the Hellenistic skene building they had originated from, and it is possible that these blocks came from the Hellenistic parodoi, which bear similar doweltailed clamp traces. In fact, it is probable that both of the limestone parodoi walls were rebuilt in the late third century B.C. when the skenotheke and mobile wooden stage were introduced ${ }^{311}$.

\section{3-7. Skene threshold}

Each of the three doorways of the niches, two hospitalia and the central valvae regia, has a threshold. Fig. 13 shows details of the west hospitalia niche stairway, the steps of which are made of limestone, not marble as seen in the Roman scene building. It is reasonably clear that the thresholds were also reused from the previous building because the steps behind the doorway also contained reused blocks from several parts of the Hellenistic theatre, including the cornice block of a statue base, which can now be observed in a step of the west hospitalia (Fig. 13). These thresholds were probably crafted from three rooms of the ground floor of the skene corresponding to the three doorways of the proskenion. Similar examples can be observed the skenes of the theatres at Priene ${ }^{32}$ and Delos ${ }^{33)}$, among others.

\section{3-8. Window flame of the thyroma}

More obviously reused blocks from the Hellenistic scene building can be seen in the case of the aulaeum (or drop curtain) of the Roman stage (Fig. 14). ${ }^{34)}$ Behind of the prosacenium wall and floor of the pulpitum, there is a row of eight limestone slabs cut into rectangular shapes approx. $0.7 \mathrm{~m}$ in length and 0.5 $\mathrm{m}$ in width, with depths between 0.15 and $0.20 \mathrm{~m}$. The slabs bear a square hole in the middle (approx. $18 \mathrm{X} 18 \mathrm{~cm}$ per side) in each to support a post for the drop curtain ${ }^{35}$. The original total height of the window frame is unknown, but the width is approx. $0.27 \mathrm{~m}$. Some of these slabs have crowning moulding that matches the window frames of the north propylon of the Asklepieion at Messene ${ }^{36}$. There are numerous examples of the Hellenistic scene building doorframe, such as the skene ground floor doorframe at Priene ${ }^{37)}$ and Delos ${ }^{38}$, among others.

\section{Estimation of the Hellenistic scene building}

Taken together, all the above-mentioned architectural findings and identifications can assist us in creating an estimation of the theatre's original form. In this section, our hypothetical estimation of the Hellenistic scene building will be discussed. Fig. 15 shows the restored Hellenistic scene building of the theatre at Priene, while Fig. 16 shows a hypothetical restoration of the proskenion foundation of the Hellenistic Messene Theatre.

\section{4-1. Estimation of the general form of the Hellenistic scene building}

The proskenion, the foundation of which is fortunately still surviving in situ, measures approx. $26.5 \mathrm{~m}$ in length. Since the stylobate length of the Hellenistic proskenion varies from 15.4 to $31.2 \mathrm{~m}$, there was no standard proskenion size during the Hellenistic period ${ }^{39)}$. From the origin of the stone scene buildings, like the Dionysus theatre at Athens ${ }^{40}$, the paraskenion was a common, but not exclusive, motif among Hellenistic theatres ${ }^{41}$. Ramps or staircases were vital to provide access for actors, although ramps were only seen in the early phase of Hellenistic scene building development, and were abandoned after the second century B.C.42). Concerning the architectural character of the Ionic attached half-column, comparisons were made with the Corinthian column of the stoas of 
the Asklepieion and the Ionic column of the Arsinoe Fountain, both of which have been dated to the beginning of the second century B.C. It is believed that the stone Hellenistic scene building might be from the same period as that of those two buildings ${ }^{43)}$. Thus, it is likely that no ramps were used, so staircases must have existed somewhere in the scene building.

Next, the lower diameter of the Ionic attached half-column can be estimated as $0.43 \mathrm{~m}$ from the above measurements. Since there are no stylobate blocks remaining in situ, the numbers of columns and intercolumniations are hypothetical. Since a proskenion usually has three doorways, with the central doorway located on the central axis of the scene building ${ }^{44)}$, the number of intercolumniations is usually an odd number. Thus, we estimated intercolumniation as follows: (stylobate length - radius of the column X 2 at both ends)/(estimated number of intercolumniation). Then,

$$
\begin{aligned}
& (26.50-0.43) / 11=2.37 \mathrm{~m} \\
& (26.50-0.43) / 15=1.74 \mathrm{~m} \\
& (26.50-0.43) / 19=1.37 \mathrm{~m}
\end{aligned}
$$

Since the intercolumniation of Ionic proskenion varies between 1.5 and $1.9 \mathrm{~m}$ in other Hellenistic theatres ${ }^{45}$, we considered $1.74 \mathrm{~m}$ to be a reasonable value for that feature.

As for the proskenion height, Vitruvius says "The height of this

'logeum' ought to be not less than ten feet nor more than twelve (Vitruv. 5.7.2.) ${ }^{46)}$." In most ways, the ideal theatre described by Vitruvius does not correspond exactly with any actual known theatre building, but since the highest stage of the Dionysus theatre proskenion in Athens is $3.59 \mathrm{~m}$, the Messene theatre stage height might be approximated at no higher than $3.6 \mathrm{~m}$. Accordingly, the standard ratio of the major elements of a Hellenistic scene building are:

Column height: Axial intercolumniation $=1: 1.63^{47)}$

Entablature height: Axial intercolumniation $=1: 0.389^{48}$

Thus, the stage height, i.e., the height of order, can be estimated as

$$
\left.(1.738 \times 1.63)+(1.738 \times 0.389)=2.83^{49}\right)+0.67=3.50 \mathrm{~m} \approx 3.5 \mathrm{~m}
$$

In this case, the ratio of the lower diameter $(0.43 \mathrm{~m})$ to the column height $(2.83 \mathrm{~m})$ is $1: 6.58^{50)}$.

Similarly, the standard ration between the height of proskenion and skene is

Proskenion height:Skene height $=2: 3^{51}$

Thus, the height of skene can be estimated as $3.49 \mathrm{X} 1.5=5.235 \mathrm{~m}$.

\section{4-2. Discussion on normal lonic column}

The critical argument of the present restoration might be the normal Ionic column drums, which were reused in the pillars of the pulpitum. Our recent fieldwork examinations have concluded that the flute sections of both the normal and half Ionic columns are exactly the same, so it is reasonable to assume that they belong to the same period. If we trust that these Ionic column drums are from the Hellenistic scene building, then, in which part these blocks were applied? There are three exceptional examples of the Hellenistic skene form: The Theatre at Apollonia in Albania possessed a Doric façade on the upper story of the skene, of which only one case can be found in mainland Greece ${ }^{52)}$. While its hypothetical restoration is supported by several pieces of evidence ${ }^{53)}$, it seems possible that the Doric colonnade could have been used in the stoa behind the scene building. The remaining two examples are two Sicilian scene buildings at Segesta and Tyndaris. According to the architectural survey by Bulle, the Segesta Theatre scene building was restored as a two-story structure (Doric lower and Ionic upper) ${ }^{54)}$, but in her study, Buckler
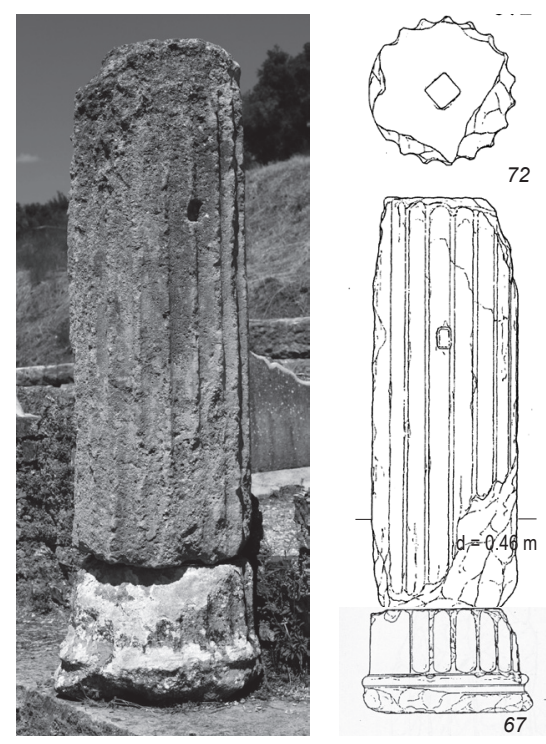

Fig. 18 (left above) Messene. Ionic column drum with base block of the Arsinoe Fountain, reconstructed, 2016 (photo by Yoshitake, R.)

Fig. 19 (right above) Messene. Ionic column drum (above, No. 72) with base block (below, No. 67) of the Arsinoe Fountain (modified by Yoshitake R., after Reinholdt 2009, pls. 16-17) scale 1:30 conjectured that the theatre was later restored to a single-floor form with an Ionic proskenion and Doric skene ${ }^{55}$. The scene building at Tyndaris also has two stories, Doric below and pilasters above ${ }^{56)}$, but Buckler again posits the restoration to a single floor structure with pilasters used for the proskenion and Doric used for the skene ${ }^{57}$. However, it should be noted that both of the abovementioned forms are based on Bulle's 1920s architectural survey, and since the number of discovered architectural blocks remains limited, Buckler's restoration theories remain hypothetical and uncertain. Moreover, the researchers who support the colonnaded façade skene have do not explain exactly how the stage actors were able to hide costumes and tools without thyromata. In this way, the idea of a 
colonnaded façade of skene is still highly unlikely.

If we trust that the Ionic column drums are from an another public building, then, the Arsinoe Fountain, which is located in the northeast of the theatre across a paved street, must be listed as the most possible candidate. This fountain was constructed between the end of third and the first half of the second century B.C., and was rebuilt in the second half of the first century A.D. ${ }^{58)}$ At the time of Roman construction, the front Doric colonnade was demolished and turned into a pair of huge basins that were divided by the middle paved passage leading to the new shrine-like three-arched façade. Fig. 17 shows the restored elevation of the Arsinoe Fountain of the second phase, when six Ionic columns from the middle colonnade were dismantled ${ }^{59}$.

It might not be coincidental that the discovered normal Ionic column of the Roman stage (Figs. 7-8) has lower diameters of 0.45 to $0.48 \mathrm{~m}$ ( 4 measurements), which precisely matches the diameter of 0.44 to $0.46 \mathrm{~m}$ ( 5 measurements) of the normal Ionic columns of the Arsinoe Fountain (Figs. $18-19)^{60}$. Comparing to twelve survived column drums from the Roman stage, it is obviously strange that only three blocks and five scattered fragments of the normal Ionic column drums of the middle colonnade of the same building. These circumstances might lead us to assume that both of the public buildings located northwest of the agora were rebuilt during the same period, and that the dismantled column drums and base were reused as pillars into the new stage of the theatre, and the capitals into somewhere of the agora. Moreover, this transportation and reuse of material could be dated to the third quarter of the first century A.D., bringing it into agreement with the dating of both Phase II of the Arsinoe Fountain (the second half of the first century A.D.), ${ }^{61)}$ and the construction phase of the Roman theatre scene building (from Claudius to Vespasian: A.D. 41-79) ${ }^{62}$. Thus, in the case of Messene, it might be reasonable to conclude that the traditional thymomata-type skene was constructed and the normal Ionic column drums of the stage most likely involved the transportation and reuse of blocks from the Arsinoe Fountain.

\section{Summary}

The results of our recent observations and architectural analyses have enabled us to provide a more comprehensive estimation of the Messene Theatre Hellenistic scene building. The Hellenistic scene building, following the traditional form, was found to have consisted of two parts: the proskenion and the skene. The proskenion, which had an approx. 26.5-m-long colonnade of Ionic attached half-columns made of poros stone, bears traces of the wooden pinakes used in their intercolumniation and the three doorways between them ${ }^{63}$. It is possibly that there were paraskenion on both side of the stage, but the staircase leading to the stage is still uncertain. Three doorways were installed behind the proskenion, each with a limestone threshold. There were possibly also three thyromata on the upper floor of the skene, which was built to provide costume changing space for the actors. The origin of the normal Ionic column drums of the pulpitum is estimated not to the concerning scene building but to another public building, most probably to the Hellenistic Arsinoe Fountain.

\section{Acknowledgment}

The research was financially supported by by the Grant-in-Aid of Japanese Ministry of Education and Science: (Basic(B), No. 16H05756, Ryuichi Yoshitake).

\section{REFERENCES}

*1) Yamazato, M. and Yoshitake, R.: Studies of Ancient Mediterranean Cities (144): Hellenistic Scene Building of the Theatre at Messene, AIJ Kyushu Chapter Architectural Research Meeting (Planning) Vol. 56, pp. 565-568, 2017.3 (in Japanese)

山里光季, 吉武隆一：地中海古代都市の研究 (144): メッセネ劇場のヘレニズム期の舞台建物について, 日本建築学会研究報告. 九州支部. 第 56 号, pp. 565$568,2017.3$.

\section{NOTES}

1) von Gerkan, A.: Das Theater von Priene. als Einzelanlage und in seiner Bedeutung für das hellenistische Bühnenwesen, Verlag für praktische Kunstwisssenschaft, Schmidt, F., 1921.

2) von Gerkan, A. and Müller-Wiener, W.: Das Theater von Epidauros, Kohlhammer, W., 1961.

3) For the general view on the Hellenistic theatre building, Bieber 1961, pp. 108-128. For the theatre at Priene, von Gerkan 1921; and for the theatre at Epidauros, von Gerkan and Müller-Wiener 1961.

4) Gogos, S.: Das Theater von Aigeira: Ein Betrag zum antiken Theaterbau, Sonderschriften des Österreichisches Archäologisches Institut 21, Österreichisches Archäologisches Institut, 1992.

5) Isler, H.P.: Das Tehater. Grabungen 1997 und 1998, Eretria. Fouilles et recherches, Vol. 18, Infolio éditions, 2007.

6) Fraisse, P. and Moretti, J.-C. : Exploration archéologique de Délos. 42, Le théâtre, École française d'Athènes, 2007.

7) Franz S. and Hinz, V.: The Architecture of the Greek Theatre of Apollonia in Illyria (Albania) and its Transformation in Roman Times, in Frederiksen, R., Gebhard, E.R. and Sokolicek, A. (eds.): The Architecture of the Ancient Greek Theatre. Acts of an International Conference at the Danish Institute at Athens 27-30 January 2012, Monography of the Danish Institute at Athens, Vol. 17, Aarhus University Press, pp. 335-349, 2015.

8) See the following two symposium books: Frederiksen, F, Gebhard, E.R., and Sokolicek, A. (eds.), The Architecture of the Ancient Greek Theatre. Acts of an International Conference at the Danish Institute at Athens 27-30 January 2012, Danish Institute at Athens; Aarhus University Press, 2015; Csapo, E., Goette, H.R., Green, J.R. and Wilson, P. (eds.), Greek Theatre in the Fourth Century B.C., Walter de Gruyter, 2014.

9) Öztürk, A.: Was Dörpfeld Right? Some Observations on the Development of the Raised Stage in Asia Minor, in Frederiksen, F., Gebhard, E. and Sokolicek, A. (eds.): The Architecture of the Ancient Greek Theatre. Acts of an International Conference at the Danish Institute at Athens 27-30 January 2012, Monography of the Danish Institute at Athens, Vol. 17, Aarhus University Press, pp. 381-389, 2015; Isler, H.P.: Traditional Hellenistic Elements in the Architecture of Ancient Theatres in Roman Asia Minor, in Frederiksen, R., Gebhard, E.R., and Sokolicek, A. (eds.): The Architecture of the Ancient Greek Theatre. Acts of an International Conference at the Danish Institute at Athens 27-30 January 2012, Monography of the Danish Institute at Athens, Vol. 17, Aarhus University Press, pp. 433-447, 2015. 
10) Note for the reused material of the Messene theatre; Yamazato and Yoshitake 2017, op. cit.

11) Spolia may not be used in this article, rather reuse. Since the terminology of architectural spolia has been used the reusing material from the late antiquity to the early medieval age, the meaning of it is not limited only to reusing construction activity but also symbolic way to show classical material in new building. Nevertheless, architectural spolia was not aim to ideological way of presentation, but to pragmatic reason (Ward-Perkins, B., 'Spoliation and Reuse of Unwanted Buildings, in From Classical Antiquity to the Middle Ages. Urban Public Building in Northern and Central Italy AD 300-850, Oxford University Press, pp. 203-229, 1984, 213-214; Deichmann, F.E.: Die Spolien in der spätantiken Architektur : vorgetragen am 5.7.1974, Sitzungsberichte der Bayerischen Akademie der Wissenschaften. Philosophisch-Historische Klasse; Jahrg. 1975, Heft 6, Beck, 1975; Deichmann, F.E.: Säule und Ordnung in der frühchristlichen Architektur, Mitteilungen des Deutschen Archäologischen Instituts, Römische Abteilung, Vol. 55, pp. 114-130, 1940). Spoliation, as opposed to spolia, is recent terminology, meaning the termination of a building's original form and purpose (Kinney, D.: Spoliation in Medieval Rome, in Alekamp, S., Carmen, M.-J. and Seiler, P. (eds.): Perspektiven der Spolienforschung. 1, Spoliierung und Transposition, Walter de Gruyter, pp. 261-286, 2013).

12) The construction phase of the roman scene building of Messene theatre is estimated by the architectural ornamentation of the scaenae frons and its contemporary buildings. Yoshitake, R.: Stylistic Analysis of the Architectural Ornamentation and Dating of the Scaenae Frons of the Theater at Ancient Messene, Journal of Architecture and Planning (Transactions of AIJ), Vol. 78, No. 684, pp. 485-495, 2013.2 (in English); 吉武隆一：古代都市メッセネの劇場のスカエナエ・フロンスに拈ける建築装飾の様式分析お よび建設年代, 日本建築学会計画系論文集, 第 78 巻, 第 684 号, pp. 485-495, 2013.2.

13) Hayashida, Y., Yoshitake, R. and Ito, J.: Architectural Study of the Stoas of the Asklepieion at Ancient Messene, Kyusyu University press, 2013 , pp. $74-75$.

14) Reinholdt, C.: Das Brunnenhaus der Arsinoë in Messene: Nutzarchitektur, Repräsentationsbaukunst und Hydrotechnologie im Rahmen hellenistisch-römischer Wasserversorgung, Phoibos Verlag, 2009, pp. 71-75.

15) The same error happens also in the cavea of the Messene theatre.

16) cf. the stylobate height of the theatre at Aigeira is varying from 13.5 to $32.5 \mathrm{~cm}$. Gogos 1992 , op. cit., p. 60 , table 13 .

17) cf. the stylobate depth of the theatre at Aigeira is varying from 46 to $67 \mathrm{~cm}$. Gogos 1992, op. cit., p. 60, table 13.

18) For the moulding of attic-type base at Messene, see: Hayashida et al. 2013, op. cit., p. 85, esp. fn. 76.

19) Hayashida et al. 2013, op. cit., p. 85, pls. 11-12.

20) Reinholdt 2009, op. cit., p. 73, figs. 104-105.

21) As the present paper discuss, reusing of the Hellenistic building material in Roman imperial period was common phenomenon in Messene. See the case of the Arsinoe Fountain. Reinholdt 2009, op. cit., pp. 130-140.

22) Themelis, P.G.: The Theatre at Messene. With a Contribution on the Masons Marks by K. Sidiropoulos, in Frederiksen R., Gebhard, E. and Sokolicek, A. (eds.): The Architecture of the Ancient Greek Theatre. Acts of an International Conference at the Danish Institute at Athens 27-30 January 2012, Monography of the Danish Institute at Athens, Vol. 17, Aarhus University Press, pp. 213-214, fig. 11.

23) Sidiropoulos, K., "The Mason's Mark from the Theatre of Messene," in Themelis 2015, op. cit., pp. 220-222, figs. 15. Such kind of reused block has been reported in other Hellenistic theatres of Peloponnesus, like as the one at Corinth. Stillwell, R.: Corinth; Results of Excavations Conducted by American School of Classical Studies at Athens (1932- ); vol. 2, The Theater, American School of Classical Studies at Athens, 1952, pp. 21, 34-35.

24) The character of mason's marks support the dating of the reusing and rebuidling at Roman imperial period; like as sigma (C) instead of standard $(\Sigma)$, small omega ( $\omega)$ instead of big omega $(\Omega)$, etc. Sidiropoulos 2015, op. cit., p. 222.

25) Some exceptional case will be discussed in the following.

26) The architrave-cornice blocks of K2.1, K2.2, K3.46 and 9284 (belongs to K3). Ito, J.: Architectural studies of the three Grave monuments in the Gymnasium complex at ancient Messene. Preliminary report, private edition, 2002, figs. 21-22, 32-33.

27) Ito 2002, op. cit., 39, fig. 32. It is also some architrave-frieze blocks of the fountain of Arsinoe can be observed, but not clear. Reinholdt 2009, op. cit., pp. 80-81.

28) Müth, S.: Eigene Wege, Topographie und Stadtplan von Messene in spätklassisch-hellenistischer Zeit, Internationale Archäologie 99; Rahmen/Westf., 2007, pp. 115-118; Ito 2002, op. cit., p. 39, fig. 60-61.

29) For dating of the Hellenistic scene building of the theatre at Messene: R. Yoshitake, "Building phase of the theatre at Messene," (unpublished).

30) Sidiropoulos 2015, op. cit., p. 222, fig. 15.

31) Yoshitake, R.: An Interpretation of the Scenery Storage Room and the Stone Lines of Hellenistic Greek Theatres, Journal of Architecture and Planning (Transactions of AIJ), Vol. 82, No. 733, pp. 783-791, 2017.3 (in Japanese); 吉武隆一：ヘレニズム期のギリシア劇場における移動式舞台建物 メッセネ、スパルタおよびメガロポリスの 比較分析, 日本建築学会計画系論文集, 第 82 巻, 第 733 号, pp. 783-791, 2017.3.

32) von Gerkan 1921, op. cit., pp. 51-59, pl. 27.

33) Fraisse and Moretti 2007, op. cit., pp. 57-58, pl. 25.

34) Yoshitake, R.: On Aulaeum of the Roma Theatre at Messene, Journal of Architecture and Planning (Transactions of AIJ), Vol. 54, pp. 697-600, 2015.3 (in Japanese); 吉武隆一 : メッセネのローマ劇場の緞帳について, 日本建築学会研究報告.九州支部.第 54 号, pp. 597-600, 2015.3.

35) For the mechanism of the aulaeum or drop curtain, see Fincker, M. and Moretti, J.-C.: Le rideau de scène dans le théâtre romain in Asensio, S.F.R. and Röring, N. (eds.): La Scaenae Frons en la Arquitectura Teatral Romana. Actas del Symposium Internacional celebrado en Cartagena los días 12 al 14 de marzo de 2009 en el Museo del Teatro Romano, Universidad de Murcia, Servicio de Publicaciones, pp. 309-329, 2010; Yoshitake, R.: On Aulaeum of the Roma Theatre at Messene, Journal of Architectural Planning (Transactions of AIJ), Vol. 54, pp. 697-600, 2015.3 (in Japanese); 吉武隆一：メッセネのローマ劇場の緞帳について, 日本建築学会研究報告.九州支部.第 54 号, pp. 597-600, 2015.3.

36) Hayashida et al. 2013, op. cit., pls. 42-43, 45-47.

37) von Gerkan 1921, op. cit., pp. 51-59, pl. 27.

38) Fraisse and Moretti 2007, op. cit., pp. 54-56, blocks No. 31-38, pls. 26-27.

39) The length of the of proskenion in Hellenistic theatre is as follows; at Aigeria, $15.40 \mathrm{~m}$; at Dionysus theatre at Athens, $20,10 \mathrm{~m}$; at Piraeus, $18,27 \mathrm{~m}$; at Eretria $19,85 \mathrm{~m}$; at Dodona 31,20 m; at Sicyon 18,50 m; at Epidauros 22,53 m; at Delos 19,80 m; at Assos, 20,90 m; at Priene, 20,88 m ; at Demetrias, ca. 25 m; at Corinth, ca. $21 \mathrm{~m}$; at Isthmia, ca. 15,60m. (Gogos 1992, op. cit., p. 80, fn. 210.)

40) Christina-von Moock, P.: The Theatre of Dionysus Eleuthereus in Athens, in Csapo, E., Goette, H.R., Green, J.R., and Wilson, P. (eds.), Greek Theatre in the Fourth century B.C., Walter de Gruyter, pp. 15-76, 2014.

41) The Hellenistic scene building with paraskenion can be seen on the following theatres at Epidauros, Oiniadai, Demetrias, at Dodona; in contrast, no paraskenion on the following theatres; at Priene, at Oropos, at Corinth, at Isthmia, Sicyon, Elis and Thespiai (Gogos 1992, op. cit., p. 75, fn. 185).

42) Watanabe, M.: On Ramps and paraskenion of Greek-Hellenistic Theaters, AIJ Kyushu Chapter architectural research meeting, Vol. 54, pp. 601-604, 2015.3 (in Japanese); 渡邉 道治 : ギリシア:ヘレニズム時代の劇場の斜路とパラスケニオンについて, 日本建築学会研究報告. 九州支部. 第 54 号, 601-604 頁, 2015.3.

43) See note 29).

44) Watanabe, M.: On proskenion of so-called Greek-type Theatres in Greek and Hellenistic Period, AIJ Kyushu Chapter architectural research meeting, Vol. 56, pp. 581-584, 2017.3 (in Japanese), esp. p. 584; 渡邊道治: ヘレニズム期までのギリシア型劇場のプロスケニオンについて, 日本建築学会研究報告.九州支部. 第 56 号, pp. 
581-584, 2017.3.

45) The axial intercolumniation of the Ionic proskenion is as follows; at Sicyon, $1.45 \mathrm{~m}$ (Fiechter, E. R.: Antike griechische Theaterbauten, 1: Das Theater in Oropos, W. Kohlhammer, 1930, p. 15); at Corinth, 1.67 m (Stillwell, R.: Corinth; Results of Excavations Conducted by American School of Classical Studies at Athens (1932- ); vol. 2, The Theater, American School of Classical Studies at Athens, 1952, p. 40); at Epidauros, 1.733 m (von Gerkan - Müller-Wiener 1961, op. cit., plate 21); at Oiniadai, 1.5 m (Gogos, S.: Das antike Theater von Oiniadai. Mit einem Beitrag zur Akustik des Theaters von Georgios Kampourakis, Phoibos, 2009, p. 191, plan 19).

46) Morgan, M. H. (trans.), Vitruvius. The Ten Books on Architecture, Dover Publications, p. 151, 1960.

47) Ratio of column height to axial intercolumniation of proskenion in Hellenistic theatre is as follows; at Sicyon, 1:1.76 (Fiechter, E. R.: Antike griechische Theaterbauten, 3: Das Theater in Sikyon, W. Kohlhammer, 1931, pp. 15, 28-29; axial intercolumniation = $1.45 \mathrm{~m}$, column height $=$ ca. $2.55 \mathrm{~m}$ ), at Oiniadai, 1:1.45 (Gogos 2009 , op. cit., pp. 190-191, plans 18, 19; axial intercolumniation $=1.5 \mathrm{~m}$, column height $=2.18 \mathrm{~m})$, at Aigeira, 1:1.549 (Gogos 1992, op. cit., pp. 80-82, table 16, plate 50; axial intercolumniation $=1.33 \mathrm{~m}$, column height $=2.06 \mathrm{~m}$ ), at Eretria, 1:1.64 (Fiechter, E. R.: Antike griechische Theaterbauten, 8: Das Theater von Eretria, W. Kohlhammer, 1937, p. 35, fig. 29; axial intercolumniation $=$ ca. $1.50 \mathrm{~m}$, column height $=$ ca. $2.45 \mathrm{~m}$ ), at Dionysus theatre of Athens, 1:2.01 (Fiechter, E. R.: Antike griechische Theaterbauten, 6: Das Dionysos-Theater in Athens, II: Die Sculpturen vom Bühnenhaus, W. Kohlhammer, 1936, plate 4; column height = ca. $1.7 \mathrm{~m}$, axial intercolumniation = 1.34 m), at Oropos, 1:1.391 (Dörpfeldm, W. and Reisch, E.: Das griechische Theater : Beiträge zur Geschichte des Dionysos-Theaters in Athen und anderer griechischer Theater. Barth \& von Hirst, 1896, p. 104; Fiechter 1930, op. cit., p. 17, plate 3; column height $1.887 \mathrm{~m}$, axial intercolumniation $=1.356 \mathrm{~m}$ ); thus, the average is 1:1.63.

48) Ratio of entablature height to axial intercolumniation of proskenion in Hellenistic theatre is as follows; at Sicyon, 1:0.379 (Fiechter 1931, pp. 15, 28; entablature height = ca. $0.55 \mathrm{~m}$, axial intercolumniation $=1.45 \mathrm{~m}$ ), at Corinth, 1:0.359 (Stillwell 1952, pp. 40,106-110; entablature height $=$ ca. $0.6 \mathrm{~m}$, axial intercolumniation $=1.67 \mathrm{~m}$ ), at Epidauros, 1:0.446 (von Gerkan - Müller-Wiener 1961, plate 21; entablature height $=0.773 \mathrm{~m}$, axial intercolumniation $=1.733 \mathrm{~m}$ ), at Oiniadai, 1:0.373 (Gogos 2009, pp. 190-191, plans 18,19 ; entablature height $=0.36 \mathrm{~m}$, axial intercolumniation $=1.5 \mathrm{~m}$ ); thus, the average is 1:0.389.

49) If we determine the column height from the amount of tapering to the cylinder height, the column height $=(($ lower diameter) - (upper diameter) $) \mathrm{X}((\mathrm{av}$. Column drum height $)$ (av. Amount of column drum tapering)); $(0.414-0.34) \mathrm{X}(1.269 / 0.039)=2.408 \mathrm{~m}$.

50) Ratio of the column height to the lower diameter is varying from 1:5 (Dionysus theatre at Athens) to 1:8.24 (theatre at Sicyon). (Gogos 1992, op. cit., pp. 82-83, table 3) In the case of Epidauros, the theatre of which has Ionic attached half-column as like as Messene, it is 1:7.691 (von Gerkan - Müller-Wiener 1961, op. cit., p. 19, fig. 13, pl. 21). More useful comparison is the ratio both of the middle Ionic colonnade of the Arsinoe Fountain, which is $0.46 \mathrm{~m}: 3.575 \mathrm{~m}=1: 7.77$ (Reinholdt 2009, op. cit., pp. 71-75).

51) Ratio of the height of skene to the height of proskenion in Hellenistic theatre is as follows; at Oropos, 1:1.5 (Sear, F.: Roman theatres. An architectural study, Oxford University Press, 2010, p. 403; proskenion height $=2.46 \mathrm{~m}$, skene height $=3.69 \mathrm{~m}$ ), at Priene, 1:1.43 (von Gerkan 1921, op. cit., p. 69 , fig. 8, Tafel 33.3; proskenion height $=2.723 \mathrm{~m} ;$ skene height $=3.90 \mathrm{~m}$ ), at Epidauros, 1:1.6 (Gogos, S: Das Theatre von Epidauros. Mit einem Beitrag zur Akustik des Theaters von Georgios Kampourakis, Phobios, 2011, pp. 61-62; von Gerkan - Müller-Wiener 1961, op. cit., p. 73, Tafel 29b; proskenion height = $3.52 \mathrm{~m}$; skene height = ca. $3.52 \mathrm{~m}$ ), at Aigeria 1:1.5 (Gogos 1992, op. cit., p. 82, esp. fn. 226, plate 50; proskenion height $=$ ca. $2.66 \mathrm{~m})$, at Oiniadai, 1:1.66 (Gogos 2009, op. cit., pp. 71-72, 191, plan 19; proskenion height $=2.54 \mathrm{~m}$; skeke height $=4.22 \mathrm{~m})$.

52) Franz S. and Hinz, V.: The Architecture of the Greek Theatre of Apollonia in Illyria (Albania) and its Transformation in Roman Times, in R. Frederiksen, E.R. Gebhard and A. Sokolicek (eds.): The Architecture of the Ancient Greek Theatre. Acts of an International Conference at the Danish Institute at Athens 27-30 January 2012, Monography of the Danish Institute at Athens, Vol. 17, Aarhus University Press, pp. 335-349, 2015; Fiedler, M., Franz, S. and Gjonfecaj, S.: Neue Forschungen zum hellenistisch-römischen Theater von Apollonia (Albanien), Mitteilungen des Deutschen Archäologischen Instituts, Römische Abteilung, Vol. 117, pp. 55-200, 2011; Angelinoudi, A. and Bäuerlein, J.: The Theatre of Apollonia (Albanien). Ein Vorbericht, Mitteilungen des Deutschen Archäologischen Instituts, Römische Abteilung, Vol. 114, pp. 17-29, 2008.

53) Franz and Hinz 2015, op. cit., pp. 339-341. The reasons to support their Doric colonnade of the skene are: 1) discovered architectural fragments were unearthed, i.e. not belong to the ground level, 2) no related building which can adopt these Doric colonnade, 3) column shaft bear broad plain facets on one or both flutes in the presumed axis, etc.

54) Bulle, H., Untersuchungen an Griechischen Theatern, Verlag der Bayerischen Akademie der Wissenschaften; In Kommission des Verlags R. Oldenbourg, 1928, pp. 110-131, pls. $19-32$.

55) Buckler, B.: Two Sicilian skenai. A modified view, Archäologischer Anzeiger, pp. 277-293, 1992, esp. pp. 279-289, figs. 1, 5.

56) Bulle 1928, op. cit., pp. 131-152, pls. 33-41.

57) Buckler 1992, op. cit., pp. 289-293, figs. 9, 11.

58) Reinholdt 2009, op. cit., pp. 130, 135. The dating is supported by based on the several evidences of architectural character, inscriptions, introduction of the arch technique in roman time, etc.

59) Reinholdt 2009, op. cit., pp. 173-174, figs. 116-117, 143-144.

60) Reinholdt 2009, op. cit., pp. 77, 219-220, figs. 108-109, pls. 17-18. Another candidate of reusing source can be the North Stoa of the Agora, the diameter of which is unknown; but clearly bigger than the one of the Stoas of the Asklepieion ( $0.626 \mathrm{~m}$ of outer order; $0.710 \mathrm{~m}$ of inner order) (Hayashida et al. 2013, op. cit., p. 161, table 25).

61) Reinholdt 2009, op. cit., pp. 129-132.

62) Yoshitake 2013, op. cit., p. 491.

63) According to Moretti, painted wooden panel was so expensive (130 drachmas per a panel without the fir-wood!), that panels were possibly put into the stage when it was not use. Moretti, J-C.: The Evolution of Theatre Architecture Outside Athens in the Fourth Century, in Csapo, E., Goette, H.R., Green, J.R. and Wilson, P. (eds.), Greek theatre in the fourth century B.C., Walter de Gruyter, pp. 107-137, 2014, esp. p. 129; Fraisse and Moretti 2007, op. cit., p. 240. 


\section{和文要約}

古代ギリシア劇場の舞台建物に関しては、プリエネやエピダウロ スなど劇場遺構の調査研究によって、高いステージ（プロスケニオ ン／ロゲイオン）と 2 階建てのスケーネで構成されることが知られ ている。ギリシアや小アジアに残るその他の舞台建物については、 後代の改築を受けた影響で、長年資料が不足していた。東地中海の ヘレニズム期の舞台建物の多くが、ローマ時代には改築されたから である。近年の発掘調査の進展により多くのギリシア劇場の研究成 果が公開されたことで、ヘレニズム期の舞台建物が再び活発に研究 されている。とくにヘレニズム期の舞台建物の解体とローマ時代に おける舞台建物への建て替えのプロセスは、建築史研究者の間で盛 んに調査されている。メッセネ劇場のヘレニズム期の舞台建物の事 例は、現存する帝政ローマ時代の舞台建物の大半がヘレニズム期の 建築部材を転用していることがよく観察できる重要遺構である。以 上の背景から、本稿ではメッセネ劇場の舞台建物とその転用材の現 地調査結果を報告するとともに、類例と比較しつつへレニズム期の 舞台建物を推定した。

筆者らが 2016 年に現地調査を行った結果、メッセネのローマ時 代の舞台建物のほとんどがヘレニズム期の舞台建物からの転用材で あり、計画的に転用されたことが確認できた（Figs. 1-2）。まず、ロ ーマ時代の舞台下に残る長さ約 $26.5 \mathrm{~m}$ の二列のポロス石の石列は、 ヘレニズム期のプロスケニオンの基礎である（Fig. 3)。ローマ時代 のプロスカエニウム壁の内部には、ポロス石の基礎が一部観察でき ることから、両翼にパラスケニオンがあった可能性がある。次に、 スカエナエ・フロンスの三つの壁弇 (ニッチ) には、平な石灰岩が 敷き詰められており、随所にダボや鎹の痕跡が観察できる（Fig. 4)。 正面から見える石材の厚みは $0.23 \sim 0.30 \mathrm{~m}$ で、これらはプロス ケニオンの基礎に直接置かれていたスタイロベイト部材の転用と考 えられる。床に敷き詰めるために転用前の部材奥行き寸法は不明だ が、最大值で $0.53 \mathrm{~m}$ あり、後述のイオニア式半円柱部材の奥行き 約 $0.50 \mathrm{~m}$ とほぼ一致する。

ローマ時代の木造ステージを支える 18 本の床柱は、すべてへレ ニズム時代のイオニア式半円柱部材（Figs. 5-6）とイオニア式円柱 部材を高さ約 $1.2 \sim 1.3 \mathrm{~m}$ に揃えて切断して転用したものである (Figs. 7-8)。イオニア式半円柱の両側面には幅約 $15 \mathrm{~cm}$ の溝があ り、柱間に差し込んだ木製の背景画パネルを固定したと考えられる。 円柱のフルートは周囲 20 本で、柱礎にはアッティカ式繰形がある。 フルートの断面形状やポロス石の材質、スタッコ仕上げなどの特徴 は、同じメッセネのアスクレピオス神域のコリント式ストアやアル シノエ泉水場のイオニア式列柱に酷似している。さらに 2012 年の 調査では、メッセネのアゴラ北東部からイオニア式半円柱の柱頭が 確認された（Fig. 9)。その直径や両側面の溝の特徵がステージの床 柱に転用されたイオニア式半円柱の部材に合致することから、元々 はプロスケニオンの列柱の柱頭で後にアゴラに移設されたものと考 えられる。

ローマ時代のスカエナエ・フロンスの基壇は、ステージ床下から 直接観察することが出来る（Fig. 10）。基壇は 2 層の切石の石灰岩 で構成されており、1 層目と 2 層目で高さが異なる。さらに石材に は鋘や梃子穴が観察できるが、互いに一致していないことから転用 材であることが一目で分かる。この 2 層の基壇は、もともと二枚一
対からなるへレニズム期のスケーネ壁の石積みから転用されたもの で、1 層目は本来の切石を横に寝かせ、2 層目は元と同じ向きに積 み直したものである。その際、石材の表面にアルファベットの記号 が刻まれており、1 層目では東から西に向かって A，A-B，B- Г，... 2 層目では A A - B , B B - $\Gamma, \Delta \mathrm{B}-\Delta, \ldots$ とあって、設置順序を指示し ていたことが確認できた（Fig. 11）。基壇 3 層目は木造のステージ 床だけでなく、3つのニッチ床面を縁取る位置にある（Fig. 12）。こ の部位に転用された部材は 2 種類で、繰形からへレニズム期のスケ ーネ壁のアーキトレイブ・コーニス部材とそのバッカー（裏込め部 材）であることが判明した。さらに、3つのニッチの背後にある出 大口の敷居も (Fig. 13)、表面の痕跡などから明らかな転用材であり、 位置関係からみてヘレニズム期の舞台建物 1 階にある三部屋の敷居 であったと推定される。敷居部材の存在は、上階のスケーネのスィ ローマタ（衣装保管室）が三つであったことを示唆している。また、 舞台下のプロスカエニウム壁に沿って設置された四角い石板は（Fig. 14）、ローマ時代の緞帳に転用されたものだが、繰形の特徴からス イローマタの枠部材であったと考えられる。

現地で確認できた遺構や転用材から、ヘレニズム期の舞台建物を 推定することが可能となった（Figs. 15-16)。プロスケニオンの基 礎は原位置で確認され、その長さは約 $26.5 \mathrm{~m}$ であった。遺構の状 況からパラスケニオンが両翼に存在した可能性があるが、前 2 世紀 頃と推定されているメッセネでは斜路ではなく、内部に階段を設け てステージへのアクセスを確保したと思われる。プロスケニオンの スタイロベイトから上部は原位置では発見できなかったので、以下 の上部構造は全て推定である。まずイオニア式半円柱の下部直径が 約 $0.43 \mathrm{~m}$ であるから、柱間は 15 、心久柱間寸法は約 $1.74 \mathrm{~m}$ と推 定される。次に、プロスケニオン高さ＝オーダー高さは不明ながら、 ヘレニズム期の舞台建物では、平均すると円柱高さ：心々柱間 $=1$ : 1.63、エンタブラチュア高さ：心々柱間 $=1: 0.389$ であるから、 プロスケニオン高さは約 $3.5 \mathrm{~m}$ と推定できる。同様に、プロスケニ オン高さ：スケーネ高さ＝約 $2: 3$ であるから、スケーネ高さは約 $5.2 \mathrm{~m}$ と推定できた。

現存する遺構で発見された転用材の解釈において、イオニア式円 柱の出自がヘレニズム期の舞台建物の推定において最も重要であろ う。イオニア式円柱がヘレニズム期の舞台建物から転用されたと考 える場合、スケーネに列柱ファサードがあったとするアポロニア、 セゲスタ、ティンダリスの推定案がある。しかしアポロニアの復元 案では近くのドリス式ストアの部材が混入している疑いが拭えず、 後の 2 案は 1920 年代から詳しい資料が明らかになっておらず、現 在まで異論が多い。逆にイオニア式円柱が周囲の建物からの転用材 と考える場合、アルシノエの泉水場（Fig. 17）が重要な候補として 挙げられる。この泉水場では、ローマ時代に正面のドリス式列柱を 取り払い、内部にあったイオニア式列柱の中央部 6 本を取り払って 三連アーチのある神殿風入口を増築した。そのイオニア式列柱の部 材は僅かしか残っていないが、劇場のイオニア式半円柱の直径やフ ルート数などが全く同じである（Figs. 18-19)。さらにアルシノエ の泉水場が改築されたネ口帝の時代は、劇場の舞台建物が改築され たフラウィウス朝とほぼ同時期である。以上のことから、メッセネ のヘレニズム期のスケーネに列柱ファサードはなく、伝統的ないわ ゆる「スィローマタ・タイプ」であった可能性が高いと考えられる。 (2018 年 3 月 7 日原稿受理, 2018 年 10 月 12 日採用決定) 